\title{
Остър серозен отит - лечение и усложнения
}

\author{
Д. Попова, С. Въбранова \\ УМБАЛ „Царица Йоанна“ при МУ - София \\ Катедра по УНГ-болести
}

\begin{abstract}
Otitis media is the most common diagnosis in children, affecting two thirds of all children by the age of two years. Children with persistent OME have significant hearing loss and structural abnormalities of the eardrum or middle ear. Tympanostomy tubes are an important tool in the treatment of chronic otitis media in children. Successful management requires the use of appropriate indications and the proper selection of tube type. Long term complications are following tympanostomy tube insersion
\end{abstract}

\section{Въведение}

Острият серозен отит (OME) се дефинира като наличие на течност в средното ухо без признаци или симптоми на остра инфекция. $(1,2)$ Персистиращият излив в средното ухо води до намалена подвижност на тъпанчевата мембрана и се явява като бариера на звуковата вълна.Поради тази причина намалението на слуха се явява като единствената характеристика на заболяването. При някои пациенти този симптом може да варира и оплакванията се свеждат до запушено, заглъхнало ухо. При малките деца не се забелязва ясна реакция спрямо говор, особено в шумна среда и увеличаване звука на телевизора. ОМЕ се появява спонтанно в резултат най-често на нарушена функция на евстахиевата тръба или на усложнение на остър среден отит. По данни на Американската академия на педиатрите и Американската академия на оториноларинголозите (ААР/AАО) между 80-90\% от децата преди училищна възраст боледуват от ОМЕ. През първата година от живота им се разболяват около $50 \%$ от децата, през втората година около - $60 \%$.

\section{Методи на изследване}

Възрастта, при която се наблюдава серозният отит, е между седеммесечна възраст и шест години, един от основните симптоми е намалението на слуха, което в тази възраст при продължително персистиране на заболяването води до променено говорно развитие. Клиниката на заболяването в повечето случай протича безсимптомно, само при някои случаи с трудно възприемане на определени звуци в шумна среда, липса на концентрация на вниманието.

При някои пациенти при дългото персистиране на OME се засяга вътрешното ухо, поради тази причина 
слуховият дефицит остава постоянен, понякога е съпътстван и със световъртеж.

Заболяването може да възникне в резултат на:

- дисфункция на евстахиевата трьба;

- алергия и имунологични фактори;

- баротравма;

- след остьр отит - при адхезията на бактерията върху възпаления назофаринкс, поради нарушаване на нормалния мукоцилиарен защитен механизъм на евстахиевата тръба и средното yxo;

- деца с аномалии на мекото небце, Down или Robin syndrom.

\section{Патофизиология}

Наблюдава се секреторна трансформация на епитела, инфилтрация с фагоцити, васкуларна пролиферация и хипертрофия на свързващата тъкан. Промените са в субепителиума, хронични промени в ламина проприа:

- Streptococcus pneumoni (SP);

- Haemophilus Influenzae (HI);

- Moraxella catharralis.

При рутинно микробиологично изследване между $40-60 \%$ от изследвания ексудат е стерилен. При изследване на полимеразната активност се установява метаболитна активност, а при прилагане на допълнителни изследвания се установява наличие на бактериален биофилм в средното ухо.

През последното десетилетие се установява нов патогенен микроорганизъм като причинител на серозен отит - Alloiococcus otitidis, не е проучена степента на патогенност в ексудата на средното ухо.

Установяването на наличие на микроорганизма в средното ухо чрез метода на polymerase chain reaction (PCR) (висока концентрация) и blood agar plate (ниска концентрация). Установява се наличие на $\operatorname{IgG}$, секреторен $\operatorname{IgA}, \operatorname{IgG} 2$, and $\operatorname{IgM}$, т.е. реакция както срещу патогенен микроорганизъм. A.otitidis е бавно растящ грам-позитивен микроорганизъм, за първи път описан през 1989 г. от Faden and Dryja, открива се между 20-60\% от изследвания ексудат при деца със серозен отит.

\section{Диагностика}

Поставянето на диагнозата серозен отит не е проблем на оториноларинголога. Проблемът е кога детето отива при лекаря за консултация, т.е. ранната диагностика осигурява по-лесно лечение и без настъпили допълнителни усложнения. Най-често използваните методи са:

1. Анамнестични данни за начало на заболяването, продължителност и наличие на асоциирани симптоми;

2. Пневматична отоскопия;

3. Да се прецени степента на слуховата загуба и нейната продължителност (времето от началото на заболяването);

4. Да се направи изследване на слуха чрез детска игрова аудиометрия;

5. Тимпанометрията е необходимо да се използва, за да се потвърди диагнозата и да се определи дали има структурни промени по тъпанчевата мембрана.

\section{Лечение}

Консервативното лечение на серозния отит е доста дискутабилно и трудно могат да се определят определени групи от медикаменти за лечение на заболяването. В повечето случаи е необходимо да се прецизират и предразполагащи към развитието на това заболяване фактори. Най-често препорьчителната начална терапия е:

- Антихистамини и деконгестанти, които не са особено ефективни;

- Антимикробни и кортикостероиди, не са ефикасни за продължителна терапия;

- Антиалергична терапия. Лечението на алергията също допринася за подобряване на състоянието на децата с OME, поради връзката на заболяването с алергичните промени на горните дихателни пътища.

\section{Индикации за тимпаностомия}

1. Хроничен, персистиращ серозен отит, децата с лека степен на клинични оплаквания е необходимо да се проследят между 3- 6 месеца;

2. Рецидивиращ серозен отит, дължащ се на:

- персистираща дисфункция на ТЕ,

- анатомични особености на базата на черепа, водещи до нарушена функция на m. tensor veli palatine,

- алергия,

- аденоидна вегетация и др. ,

- нарушена подвижност на цилиите (Kartagener syndrome - автозомно-рецесивно заболяване).

3. Намаление на слуха, водещо до нарушено говорно развитие и комуникация;

- степен по отношение на слуховата загуба риск 30-35 dB; 
4. Поява на ретракционен джоб;

5. Хемотимпаном без спонтанна резорбция; холестеролен гранулом;

6. Отворена евстахиева тръба.

7. Двустранност, продължителност на заболяването, тежест и асоциирани симптоми; усложнения:

- продължителност на заболяването от 3-4 мес., при едностранно - 6 мес.;

- парализа на n. facialis, световъртеж, менингит и др.;

\section{Хирургическо лечение}

Възможните хирургически манипулации се преценяват при всеки пациент индивидуално, като е необходимо да се вземат предвид и възможните усложнения.

Преценката е насочена в два аспекта: какво ще се случи, ако не се предприеме хирургическа интервенция и ако се предприеме такава, точно каква интервенция е необходимо да се предприеме.

1. Миринготомия

2. Миринготомия и тимпаностомия

3. Аденотомия и тимпаностомия

4. Миринготомия, тимпаностомия, аденотомия.

\section{Усложнения след тимпаностомия}

Вентилационни тръбички водят до промени в структурата на тъпанчевата мембрана и костните структури. Промените, свързани с прогресивно настъпващите усложнения, започват от тъпанчевата мембрана, овално прозорче, инкудостапедиалната става, аттик, стапес.

\section{Литература:}

1. Detection rates of bacteria in chronic otitis media with effusion in children. [J Korean Med Sci. 2004]

2. Paradise JL, Rockette HE, Colborn DK, et al. Otitis media in 2253 Pittsburgh area infants: prevalence and risk factors during the first two years of life. Pediatrics. 1997; 99: 318-333

3. Casselbrant ML, Mandel EM. Epidemiology. In: Rosenfeld RM, Bluestone CD, eds. Evidence-Based Otitis Media. 2nd ed. Hamilton, Ontario: BC Decker Inc; 2003: 147-162
С прогресирането на заболяването се обхващат и други структури на средното ухо.

Настъпилите промени са свързани с изменение в съединителната тъкан, което представлява само по себе си калцификация на съединителната тъкан. Визуализират се като варовикови плаки, които постепенно си променят твърдостта, доближавайки се до костни структури (калциев дефицит). Плаките са локализирани в ламина проприа на тъпанчевата мембрана и в другите структури на средното ухо с прогресията на заболяването. Според Пмоллер процентът на тимпаносклерозата като следствие на поставени вентилационни тръбички е $23-43 \%$.

Усложненията, които се наблюдават, най-често са:

1. Оторея - $15-50 \%$ (20\%);

2. Мирингосклероза и тимпаносклероза, без тръбички $-19 \%$, след $-48 \%$;

3. Персистираща перфорация 5-25\%;

4. Холестеатом $-7 \%$;

5. Директна травма на осикуларната верига и наличие на звукопроводно или звукоприемно намаление на слуха.

\section{Заключение}

Ранната диагностика и правилният подход при лечението на острия серозен отит е дискусионен. При избора на лечението е необходимо да се прецизират късните последици по отношение на слуха и трайните промени, настьпили в средното yхо.

4. Williamson IG, Dunleavy J, Baine J, Robinson D. The natural history of otitis media with effusion-a three-year study of the incidence and prevalence of abnormal tympanograms in four South West Hampshire infant and first schools. J Laryngol Otol. 1994; 108: 930-934

5. Coyte PC, Croxford R, Asche CV, To T, Feldman W, Friedberg J. Physician and population determinants of rates of middle-ear surgery in Ontario. JAMA. 2001; 286: 2128-2135 